Deuel, H. J. Jr. (I946). Y. Nutrit. 32,69.

Deuel. H. J. Jr. \& Hallman, L. F. (I940). F. Nutrit. 20, 227.

Deuel, H. J. Jr., Hallman, L. F. \& Leonard, A. (1940). F. Nutrit. 20, 2 r 5.

Deuel, H. J. Jr., Hallman, L. F. \& Movitt, E. (1945). F. Nutrit. 29, 309.

Deuel, H. J. Jr., Hallman, L. F., Movitt, E., Mattson, F. \& Wu, E. (1944). F. Nutrit. 27, 335 .

Deuel, H. J. Jr., Hendrick, C. \& Crockett, M. E. (1946). F. Nutrit. 3r, 737.

Deuel, H. J. Jr., Hendrick, C., Movitt, E., Crockett, M. E., Smyth, I. M. \& Winzler, R. J. (1946). F. Nutrit. 3I, 747 .

Deuel, H. J. Jr. \& Holmes, A. D. (1921). Amer. F. Physiol. 54, 479.

Deuel, H. J. Jr. \& Holmes, A. D. (1922). Bull. U.S. Dep. Agric. no. I033.

Deuel, H. J. Jr. \& Movitt, E. (1944). F. Nutrit. 27, 339.

Deuel, H. J. Jr. \& Movitt, E. (1945). F. Nutrit. 29, 237.

Deuel, H. J. Jr., Movitt, E. \& Hallman, L. F. (1943). Science, 98, 139.

Deuel, H. J. Jr., Movitt, E. \& Hallman, L. F. (I944). F. Nutrit. 27, 509.

Deuel, H. J. Jr., Movitt, E., Hallman, L. F. \& Mattson, F. (1944). F. Nutrit. 27, ro7.

Euler, B. v., Euler, H. v. \& Rönnestam-Saberg, I. (1947). Ark. Kemi Min. Geol. [B], 25, no. 2.

Euler, B. v., Euler, H. v. \& Säberg, I. (1942). Ernährung, 7, 65.

Euler, B. v., Euler, H. v. \& Saberg, I. (1943). Ernährung, 8, 257.

Golding, J., Soames, K. M. \& Zilva, S. S. (1926). Biochem. Y. 20, 1306.

Gullickson, T. W. \& Fountaine, F. C. (1939). F. Dairy Sci. 22, 47r.

Gullickson, T. W., Fountaine, F. C. \& Fitch, J. B. (1942). f. Dairy Sci. 25, Ir7.

Harris, R. S. \& Mosher, L. M. (x940). Food Res. 5, 177.

Henderson, J. L., Jack, E. L., Lepkovsky, S. \& Reid, D. L. (1945). Y. Nutrit. 30, 169.

Henry, K. M., Kon, S. K., Hilditch, T. P. \& Meara, M. L. (1945). J. Dairy Res. 14, 45.

Hilditch, T. P. \& Thompson, H. M. (1936). Biochem. F. 30, 677 .

Hilditch, T. P. \& Meara, M. L. (1944). Biochem. F. 38, 29.

Hodgman, C. D. (Editor) (1947). Handbook of Chemistry and Physics, 3oth ed. Ohio: Chemical Rubber Publishing Co.

Holmes, A. D. (1925). Boston med. surg. Y. 192, 1210.

Jack, E. L., Henderson, J. L., Reid, D. F. \& Lepkovsky, S. (1945). F. Nutrit. 30, 175.

Jansen, B. C. P. (1948). Chem. $\mathcal{E}^{\circ}$ Ind. Supplement on the 9 th International Congress of Pure and Applied Chemistry, London, 1947, p. 13.

Kentie, A. (1947). Ned. Melk Zuiveltijdschr. r, 118.

Langworthy, C. F. (1923). Industr. Engng Chem. 15, 276.

Leichenger, H., Eisenberg, G. \& Carlson, A. J. (1948). F. Amer. med. Ass. 136, 388.

McCay, C. M. \& Maynard, L. A. (1935). F. biol. Chem. 109, 29.

Parrish, D. B., Shimer, E. R. \& Hughes, J. S. (1946). F. Nutrit. 31, 321.

Schantz, E. J., Boutwell, R. K., Elvehjem, C. A. \& Hart, E. B. (1940a). F. Dairy Sci. 23, I201.

Schantz, E. J., Boutwell, R. K., Elvehjem, C. A. \& Hart, E. B. (I940b). F. Dairy Sci. 23, 1205.

Schantz, E. J., Elvehjem, C. A. \& Hart, E. B. (1937-8). F. biol. Chem. r22, 381.

Schantz, E. J., Elvehjem, C. A. \& Hart, E. B. (1940). F. Dairy Sci. 23, 18 r.

Steenbock, H., Irwin, M. H. \& Weber, J. (1936). F. Nutrit. 12, 103.

Zialcita, L. P. \& Mitchell, H. M. (I944). Science, roo, 60.

\title{
Heated Fats as a Possible Source of Carcinogens
}

\section{By P. R. Peacock, Royal Cancer Hospital, Glasgow}

Cancer of the stomach causes more deaths in temperate zones of the world than any other form of malignant disease. It is natural, therefore, to consider whether this high incidence is attributable to some essentially human propensity or habit, or whether it is merely an inevitable consequence of an increase in expectation of life. The distribution of cancer in the population is about evenly divided between those under 65 and those over 65 , although less than one-tenth of the population is in the latter group.

Although human statistics are bound to be inaccurate, the tendency is to avoid notifying death as due to cancer unless the diagnosis is considered certain; the numbers, 
therefore, probably underestimate the real incidence of cancer. Animals, generally speaking, have a much less favourable expectation of life, and this makes it difficult to obtain comparable statistics, except for animals under conditions of special protection, such as domestic pets and animals in zoological parks. Animal statistics, though scanty, are more accurate, as they are generally based on post-mortem findings. Even so, it is difficult to find records of the incidence of adenocarcinoma of the stomach in any species of lower animal. There is, therefore, a prima facie case for investigating human habits for possible causes of gastric cancer.

Perhaps the most striking difference between the feeding habits of man and those of lower animals is that man cooks his food. In recent times he has also taken to colouring and flavouring it with synthetic chemicals of unknown potentialities.

\section{Table 1. Incidence of sarcomas in mice which survived for more than Io months after the injection of heated fats}

\begin{tabular}{lcc}
\multicolumn{1}{c}{ Substance injected } & $\begin{array}{c}\text { Temperature and } \\
\text { duration of heating }\end{array}$ & $\begin{array}{c}\text { Animals } \\
\text { affected }\end{array}$ \\
Cotton-seed oil & $340-360^{\circ}$ for $\mathrm{r} \mathrm{hr}$. & $2 / 7$ \\
Cholesterol & $270-300^{\circ}$ for $\frac{1}{2} \mathrm{hr}$. & $2 / 12$ \\
Cholesterol esters & $300^{\circ}$ for $\frac{1}{\mathrm{t} h \mathrm{hr}}$ & $0 / 29$ \\
Unheated cotton-seed oil & - & $0 / 10$ \\
Tumour extracts & - & $0 / 90$
\end{tabular}

It has been known since I 924 that many organic substances heated to high temperatures, $700^{\circ}$ or more in an atmosphere of hydrogen, can yield carcinogenic tars. Kennaway and his colleagues prepared such carcinogenic tar from yeast and from human skin, as well as from cholesterol and simple hydrocarbons; but they failed to obtain carcinogens at body temperature in reactions involving the use of catalysts (Kennaway, 1924; Kennaway \& Sampson, 1928). Several workers have reported that fats and lipids, heated to $350^{\circ}$, may develop carcinogenic properties, as tested by subcutaneous injection in mice and rats. This work was recently reviewed by the author (Peacock, 1947).

In this way we have studied cholesterol and its esters heated to $270-300^{\circ}$ and lard and cotton-seed oil heated to $350-400^{\circ}$ in vessels partially closed to prevent spontaneous combustion. Injection of such heated lipids (Table I) caused sarcomas in mice at the site of injection (Beck, 1941; Beck, Kirby \& Peacock, 1945); the earliest of these tumours was recognized ro months after the date of injection. In feeding experiments, however, simple administration of the heated fat has not so far given rise to a malignant tumour.

Steiner, Steele \& Koch (1943) injected sesame oil previously heated to $35^{\circ}$ into thirty-one mice. Three injections of $0.5 \mathrm{ml}$. at intervals of 4 weeks were made, and of nine mice which survived for 12 months, three developed sarcomas at the site of injection. The tumours were discovered in the 12 th, $13^{\text {th }}$ and 21 st months after injection. In extensive tests of extracts of 'overfried and overheated' meat, both by injection and by feeding, the same authors obtained only one sarcoma in a mouse 14 months after injection of a benzene extract of 'overfried' mixed beef, pork and suet. 
Sixteen mice in the same experiment survived for 15 months without tumour. Unfortunately the temperature at which the meat was fried is not recorded, though the cooking was carried 'to a crisp brown, somewhat past the point generally used in the preparation of human food, but without burning'.

In our earlier experiments (Beck \& Peacock, 194I) we gave rats and mice heated lard and observed, in the former species only, a marked overgrowth of the squamous lining of the fore-stomach, associated with symptoms suggesting vitamin A deficiency. The latter condition, however induced, is associated with a similar hyperplasia of the fore-stomach in rats, and is therefore not evidence of carcinogenic properties in the heated fats.

More recently, in feeding experiments on mice, we have employed co-carcinogens, of which croton oil is the best recognized, in an attempt to enhance the possible activity of potential carcinogens. Under these conditions we have seen malignant tumours of the glandular stomach in two mice, one of which also had benign and malignant tumours of the fore-stomach, after they had been maintained on a diet containing heated cotton-seed oil added daily for periods of 15 months or more. Mice dying before this age are therefore of little interest for comparative purposes, but we have records of over 300 mice aged 15 months or more, in these experiments and others, during the same time period, in which no case of cancer of the stomach has been observed.

Fuller details of these experiments, with a discussion of the histogenesis of the stomach tumours, will be published elsewhere.

Whether such small numbers can be regarded as significant is open to dispute, but it is worth remarking that in the whole world literature there are very few recorded cases of adenocarcinoma of the stomach in mice, or, indeed, in any other animal. In I 42,000 consecutive post mortems in mice, 'most of which lived to the cancer age', Wells, Slye \& Holmes ( $\mathrm{r}_{33} 8$ ) observed only three cases of adenocarcinoma of the stomach. As these mice had not been subjected to any experimental procedure, apart from breeding experiments, this may be regarded as an indication of the improbability of spontaneous adenocarcinoma of the stomach occurring in mice.

In 60,000 mice painted with tar, Twort \& Twort (1932) observed small papillomas of the fore-stomach, which has no human counterpart, but found no malignant lesion of the glandular stomach. Our own records of more than 5000 mice contain no case of cancer of the glandular stomach apart from the two mentioned in mice given heated cotton-seed oil and co-carcinogens. It is important to consider, as controls, only mice that survived beyond 15 months for gastric cancer and ro months for induced sarcoma, as these were the earliest ages at which the corresponding experimentally induced tumours occurred (Table r).

We naturally investigated the possibility that heated fats and lipids might contain one of the known carcinogenic hydrocarbons. Up to the present we have consistently failed to identify any known carcinogen in any of the heated fats tested by us. Heated fats to be examined are saponified and the unsaponifiable residue is dissolved in benzene known to be free from contaminants. The solution is examined in the ultra-violet beam and usually shows a bright blue fluorescence. The solution is chromatographed 
by pouring it through a column of alumina and the fractions are separated and eluted with ethyl alcohol or other suitable solvents, and the fluorescence spectrum of each fraction is recorded.

The limits of accuracy of our method allow us to detect $\mathbf{r}$ part in 100 million of either 3:4-benzpyrene or methylcholanthrene deliberately added to the heated fat. As the quantities employed in test injections do not exceed $0.5 \mathrm{ml}$., this would mean that sarcomas induced by such injections could not be attributed to quantities of such known hydrocarbons greater than $0.005 \mu \mathrm{g}$. In fact, such small quantities of these hydrocarbons are not known to be capable of inducing tumours. It seems, therefore, that we may be dealing with carcinogens, or co-carcinogens, of some hitherto unidentified type, and we must hope that further work will give an indication of their nature.

Beck, S. (1941). Brit. F. exp. Path. 22, 299.

Beck, S., Kirby, A. H. M. \& Peacock, P. R. (1945). Cancer Res. 5, 135.

Beck, S. \& Peacock, P. R. (1941). Brit. med. F. i, 8 r.

Kennaway, E. L. (1924). F. Path. Bact. 27, 233.

Kennaway, E. L. \& Sampson, B. (1 928). F. Path. Bact. 31, 609.

Peacock, P. R. (1947). Brit. med. Bull. 4, 364.

Steiner, P. F., Steele, R. \& Koch, F. C. (1943). Cancer Res. 3, 100.

Twort, J. M. \& Twort, C. C. (1932). F. Path. Bact. 35, 2 I9.

Wells, G. H., Slye, M. \& Holmes, H. F. (1938). Amer. Э. Cancer, 33, 223. 